\title{
Erratum: Variations in the uncoupling protein-3 gene are associated with specific obesity phenotypes
}

\author{
Annet F M van Abeelen ${ }^{1,2}$, Mariken de Krom ${ }^{2}$, Judith Hendriks ${ }^{2}$, Diederick E Grobbee ${ }^{1}$, Roger A H Adan ${ }^{2}$ \\ and Yvonne T van der Schouw ${ }^{1}$ \\ ${ }^{1}$ Julius Center for Health Sciences and Primary Care, University Medical Center Utrecht, Room STR 6.131, PO Box 85500, 3508 GA Utrecht, \\ The Netherlands and ${ }^{2}$ Department of Neuroscience and Pharmacology, Rudolf Magnus Institute of Neuroscience, University Medical Center Utrecht, \\ Universiteitsweg 100, 3585 CG Utrecht, The Netherlands \\ (Correspondence should be addressed to Y T van der Schouw; Email: y.t.vanderschouw@umcutrecht.nl)
}

\begin{abstract}
The authors and the journal apologize for an error in the above paper which appeared in 158 (5) 669-676. In this paper, on page 671, the fifth sentence should appear as follows 'Each mixture consisted of $1 \mu \mathrm{l}(8 \mathrm{ng})$ genomic DNA, $0.125 \mu \mathrm{l} 40^{*}$ assay mix (Applied Biosystems), and $2.5 \mu \mathrm{l}$ TaqMan Universal Master Mix (Applied Biosystems)'.
\end{abstract}

European Journal of Endocrinology 15987 